\title{
U⿱宀⿻三丨口
}

\section{Renegotiating Social Citizenship in the Age of Devolution}

Simpson, M. (2017). Renegotiating Social Citizenship in the Age of Devolution. Journal of Law and Society, 44(4), 646-673. https://doi.org/10.1111/jols.12061

Link to publication record in Ulster University Research Portal

\section{Published in:}

Journal of Law and Society

Publication Status:

Published (in print/issue): 01/12/2017

\section{DOI:}

10.1111/jols.12061

\section{Document Version}

Author Accepted version

\section{General rights}

Copyright for the publications made accessible via Ulster University's Research Portal is retained by the author(s) and / or other copyright owners and it is a condition of accessing these publications that users recognise and abide by the legal requirements associated with these rights.

\section{Take down policy}

The Research Portal is Ulster University's institutional repository that provides access to Ulster's research outputs. Every effort has been made to ensure that content in the Research Portal does not infringe any person's rights, or applicable UK laws. If you discover content in the Research Portal that you believe breaches copyright or violates any law, please contact pure-support@ulster.ac.uk. 
This is the peer reviewed version of the following article:

M Simpson, 'Renegotiating social citizenship in the age of devolution' (2017) 44(4) Journal of Law and Society 646

It has been published in final form at

http://onlinelibrary.wiley.com.proxy1.athensams.net/doi/10.1111/iols.12061/full. This article may be used for non-commercial purposes in accordance with Wiley Terms and Conditions for SelfArchiving.

\title{
Renegotiating social citizenship in the age of devolution
}

\begin{abstract}
The period 2012 to 2016 saw important developments in the role of the UK's devolved legislatures in shaping citizens' social rights. Near-uniformity in social security is being eroded, with some competences devolved to Scotland and Northern Ireland proceeding with limited divergence from Great Britain. This turn to regionalisation is linked with dissatisfaction with UK government policy. This article examines developments from a social citizenship perspective. Welfare regionalism is a challenge to Marshall's perceived unitary view of citizenship. Yet the emergence of support for divergence from differences of perspective on the state's duty to support citizens' economic welfare and the citizen's reciprocal obligations emphasises the continued relevance of Marshallian theory. As the democratisation of political rights gave birth to social rights in the early $20^{\text {th }}$ century, the regionalisation of democratic citizenship has allowed alternative visions for social citizenship to be articulated and begin to shape the emerging devolved social security systems.
\end{abstract}

\section{INTRODUCTION}

Legislative devolution has brought changes in the social rights of citizens in the UK's component regions. ${ }^{1}$ However, the maintenance of near-uniformity in social security prior to 2012 meant regionalisation of social citizenship remained limited. The Cameron governments, despite the Conservative Party's view of devolution as "constitutional vandalism," ${ }^{2}$ would oversee the most significant regionalisation of responsibility for income maintenance since the foundation of the modern welfare state. This thus-far limited process challenges interpretations of Marshall's social citizenship theory that situate responsibility for citizens' economic welfare with the nation state. ${ }^{3}$ This article suggests divergence can be reconciled with Marshallian citizenship if subnational political units hold and pursue different perspectives on the nature of the associated social rights.

The period between 2012 and 2016 saw Scotland and Northern Ireland take steps towards greater regional autonomy in social security Through analysis of political and legal developments, and of interviews with policymakers, the article presents empirical evidence that regional differences in ideologies of social citizenship provide a partial explanation for this process. Devolved-level elites

\footnotetext{
${ }^{1}$ D Birrell, The impact of devolution on social policy (Bristol: Policy Press, 2009); D Birrell and AM Gray, 'Social policy in the devolved administrations' in $\mathrm{H}$ Bochel and $\mathrm{M}$ Powell, The coalition government and social policy: restructuring the welfare state (Bristol: Policy Press, 2016)

${ }^{2}$ Conservative Party, Invitation to join the government of Britain: the Conservative manifesto 2010 (London: Conservative Party, 2010) 83

${ }^{3} \mathrm{G}$ Mooney and C Williams, 'Forging new "ways of life"? Social policy and nation building in devolved Scotland and Wales' (2006) 26(3) Critical Social Policy 608; M Keating, 'Social citizenship, solidarity and welfare in regionalised and plurinational states' (2009) 13(5) Citizenship Studies 501
} 
This is the peer reviewed version of the following article:

M Simpson, 'Renegotiating social citizenship in the age of devolution' (2017) 44(4) Journal of Law and Society 646

It has been published in final form at

http://onlinelibrary.wiley.com.proxy1.athensams.net/doi/10.1111/iols.12061/full. This article may be used for non-commercial purposes in accordance with Wiley Terms and Conditions for Self-

Archiving.

have clear concerns with UK Government reforms (not uncontroversial in England) that can appear at odds with conceptions of Marshall as an advocate of extensive, largely unconditional welfare provision as an engine of greater equality. A combination of concern about UK government policy and a desire to use devolution to find a better way underpin a growing welfare regionalism that to a large extent transcends the unionist-nationalist divide. Section 1 introduces the Marshallian account of the emergence of social citizenship, its link to a minimum standard of living and the challenge potentially posed by devolution. This is followed in section 2 by a brief description of the empirical study from which the findings flow. Section 3 gives an overview of key social security reforms under the Cameron governments, which sections 4 and 5 suggests are at odds with both common interpretations of Marshall as favouring a generous welfare state with light-touch conditionality and the aspirations of Scottish devolved elites in particular. Section 6 highlights these divergent ideologies, and their translation into policy, as a challenge to views of the nation state as the natural locus of social citizenship, but argues that, contrary to his depiction as a welfare unionist, this is compatible with Marshall's account of social rights as emerging from the exercise of political rights. The conclusion sums up the argument and emphasises the continued relevance of Marshallian theory to a decentralising UK.

\section{SOCIAL CITIZENSHIP IN THE DEVOLUTION ERA}

Marshall breaks down citizenship into three elements: civil, political and social. The social element confers:
"the whole range from the right to a modicum of economic welfare and security to the right to share to the full in the social heritage and to live the life of a civilised being according to the standards prevailing in the society." ${ }^{4}$

This core vision of a state's responsibility to "fulfil normative expectations about how the basic requirements of... personal welfare and development can be met," ${ }^{5}$ so that citizens can meet their basic needs and enjoy a reasonable level of social participation, remains the starting point for much academic discussion of social rights. Townsend, lynchpin of the 1960s 'rediscovery of poverty', defines poverty as "resources... so seriously below... the average" that the individual is "excluded from ordinary living patterns, customs and activities." ${ }^{6}$ This relative conception of poverty, grounded in the principle that economic welfare is compromised by lack of access to the goods, services and activities that comprise a normal lifestyle in a society, even if physical necessities are within reach, ${ }^{7}$ has been widely embraced. The European Council and Commission refer to "income... so inadequate as to preclude... a standard of living considered acceptable," encompassing

\footnotetext{
${ }^{4}$ TH Marshall, 'Citizenship and social class' in TH Marshall and T Bottomore, Citizenship and Social Class (London: Pluto, 1992) 8

${ }^{5} \mathrm{~N}$ Harris, Law in a complex state: complexity in the law and structure of welfare (Oxford: Hart, 2013) 4

${ }^{6} \mathrm{P}$ Townsend, Poverty in the United Kingdom (London: Penguin, 1979) 31

${ }^{7}$ D Gordon, 'The concept and measurement of poverty' in C Pantazis, D Gordon and R Levitas (eds), Poverty and Social Exclusion in Britain (Bristol: Policy Press, 2006)
} 
This is the peer reviewed version of the following article:

M Simpson, 'Renegotiating social citizenship in the age of devolution' (2017) 44(4) Journal of Law and Society 646

It has been published in final form at

http://onlinelibrary.wiley.com.proxy1.athensams.net/doi/10.1111/iols.12061/full. This article may be used for non-commercial purposes in accordance with Wiley Terms and Conditions for Self-

\section{Archiving.}

"activities... that are the norm for other people." ${ }^{8}$ Other authors explicitly link poverty to

"deprivation of social citizenship" ${ }^{9}$ or "denial of citizenship." ${ }^{10}$ The Europe 2020 strategy $^{11}$ indicates that EU states generally accept responsibility for poverty reduction.

International law, too, indicates that the citizen has a right not to mere survival, but to be protected from falling too far below a normal standard of living. The right to an adequate standard of living in article 11 ICESCR encompasses food and housing that are culturally acceptable as well as physically adequate $^{12}$ and participation in "the everyday life of society." ${ }^{13}$ Similarly, the European Committee of Social Rights and International Labour Organisation base their assessments of an acceptable income on a proportion of typical earnings or income. ${ }^{14}$ This approach was also reflected in the former UK child poverty legislation, which defined poverty as an income below a minimum proportion of the median in the current year, three of the last four years or a benchmark year, or insufficient to purchase a list of items deemed necessary for a normal lifestyle. ${ }^{15}$

That there is a social element to citizenship seems uncontroversial. The detail of social citizenship is more contested. Marshall's teleology, with civil, political and social citizenship emerging in that order, has been criticised as privileging the experience of British males at the expense of other societies or social groups in which the rights of citizenship were acquired differently, ${ }^{16}$ neglecting the

\footnotetext{
${ }^{8}$ Council of the European Union, 'Joint report by the Commission and the Council on social inclusion' (7104/04, Brussels, 5 March 2004) 8

${ }^{9}$ N Harris, 'Youth, citizenship and welfare' (1992) 3 Journal of Social Welfare and Family Law 175, 177

${ }^{10}$ Fondation Roi Baudouin, ATD Quart Monde Belgique and Union des Villes et Communes belges, Rapport général sur la pauvreté (Brussels: Ministre de l'Intégration Sociale, 1994) 394

${ }^{11}$ European Commission, 'Europe 2020 targets' (Brussels: European Commission, 2015)

<http://ec.europa.eu/europe2020/europe-2020-in-a-nutshell/targets/index_en.htm>

${ }^{12}$ Committee on Economic, Social and Cultural Rights, 'General comment 12: the right to adequate food (article 11)' (E/C.12/1999/5, Geneva: United Nations, 1999); Committee on Economic, Social and Cultural Rights, 'General comment no 4: the right to adequate housing (art. 11 (1) of the Covenant)' (sixth session, 1991) (Geneva: United Nations, 1991)

${ }^{13}$ World Bank, 'World development report 1990: world development indicators' (Oxford: Oxford University Press, 1990) 26

${ }^{14}$ International Labour Organisation, 'Direct Request (CEACR) - adopted 2007, published 97th ILC session (2008): Social Security (Minimum Standards) Convention, 1952 (No. 102) - United Kingdom' (Geneva: ILO, 2007); Committee of Independent Experts, Conclusions XIV-2 vol 1 (Strasbourg: Council of Europe, 1998-2000) 49-52; European Committee of Social Rights, European Social Charter: conclusions XX-2 (2013) (Great Britain) (Strasbourg: Council of Europe, 2014) 18, 22

${ }^{15}$ Child Poverty Act 2010 c9 s2-6; repealed by Welfare Reform and Work Act 2016 c7 s7

${ }^{16}$ T Bottomore, 'Citizenship and social class, forty years on' in TH Marshall and T Bottomore, Citizenship and Social Class (London: Pluto, 1992); B Siim, 'Gender and citizenship. problems of exclusion and Inclusion in Europe' (European citizenship: beyond borders across identities, Brussels, April 2000); J Møller and S-E Skaaning, 'Marshall revisited: the sequence of citizenship rights in the 21st century' (2010) 14(1) Government and Opposition 457
} 
This is the peer reviewed version of the following article:

M Simpson, 'Renegotiating social citizenship in the age of devolution' (2017) 44(4) Journal of Law and Society 646

It has been published in final form at

http://onlinelibrary.wiley.com.proxy1.athensams.net/doi/10.1111/iols.12061/full. This article may be used for non-commercial purposes in accordance with Wiley Terms and Conditions for Self-

Archiving.

interdependence of the three elements ${ }^{17}$ and omitting other potential elements of citizenship. ${ }^{18}$ More important when assessing the contemporary meaning of social citizenship is the lack of consensus as to what level of economic welfare the state ought to guarantee citizens and the extent to which this guarantee should be contingent on the discharge of reciprocal responsibilities. When disagreements about these matters occur between tiers of government, a further presumption about the social rights of citizenship - that they should be uniform across the state, defined and perhaps also realised by central government - can come under pressure. It is this process with which the article is chiefly concerned. Empirical findings reveal how political disagreement about the standard of living the state ought to support and the conditions it ought to impose underpin a challenge to the constitutional division of responsibility for economic welfare, and may in time result in regional divergence in the social rights of citizenship.

\section{THE PROJECT: EVOLUTION AND DEVOLUTION OF SOCIAL CITIZENSHIP}

The article flows from a socio-legal study of social citizenship in the UK bookended by the Cameron governments' flagship social security Acts: the Welfare Reform Act 2012 and the Welfare Reform and Work Act 2016. This period took in Scotland's independence referendum and subsequent renegotiation of its devolution settlement, as well as a protracted political impasse in Northern Ireland over the region's own Welfare Reform Bill that at times appeared to throw into question the future of devolution. Law does not exist in isolation from a society and a political system, but serves as "an instrument for achieving social justice"19 through its role as governments" "principal tool used... to deliver social and economic policy." ${ }^{20}$ Social security law has a particularly strong connection to the interpretation of social justice held by the government of the day. However, constitutional law is not unaffected. According to the mirror thesis, the vision for social justice embodied by the law should reflect the needs and desires of society; but if, in a multinational state, the mirror reflects only the dominant region's (England's) view of social justice, pressure for greater autonomy or independence may result. ${ }^{21}$ Constitutional upheaval in Scotland and Northern Ireland has been intimately linked to political reaction to the UK government's social security policy and underpinning view of social justice.

\footnotetext{
${ }^{17}$ M Lister, “Marshall-ing” social and political citizenship: towards a unified conception of citizenship' (2005) 40(4) Government and Opposition 471; E Palmer, Judicial review, socio-economic rights and the Human Rights Act (Oxford: Hart, 2007)

${ }^{18}$ AM Rees, 'TH Marshall and the progress of citizenship' in M Bulmer and AM Rees (eds), Citizenship today: the contemporary relevance of TH Marshall (Routledge, 1996) 13; G Delanty, Citizenship in a global age: society, culture and politics (Open University Press, 2000) 18

${ }^{19}$ DJ Galligan, 'Legal theory and empirical research' in P Cane and HM Kritzer (eds), The Oxford handbook of empirical legal research (Oxford: Oxford University Press, 2010) 983

${ }^{20} \mathrm{M}$ Partington, 'Empirical legal research and policy-making' in P Cane and HM Kritzer (eds), The Oxford handbook of empirical legal research (Oxford: Oxford University Press, 2010) 1003;

${ }^{21}$ BZ Tamanaha, 'Law and society' in D Patterson (ed), A companion to philosophy of law and legal theory (Hoboken: Wiley-Blackwell, 2010) 369
} 
This is the peer reviewed version of the following article:

M Simpson, 'Renegotiating social citizenship in the age of devolution' (2017) 44(4) Journal of Law and Society 646

It has been published in final form at

http://onlinelibrary.wiley.com.proxy1.athensams.net/doi/10.1111/iols.12061/full. This article may be used for non-commercial purposes in accordance with Wiley Terms and Conditions for Self-

Archiving.

The empirical element of the study was concerned with the reshaping of the social rights of citizenship through the eyes of devolved elites. Insights were gained into policymakers' views on UKlevel developments, moves towards greater autonomy in social security and priorities for a nascent Scottish or Northern Irish social security system, and the perspectives on a minimum standard of living and the relative responsibilities of state and citizen for the citizen's economic welfare that underpin these aspirations. The 36 participants consisted of nine Scottish and nine Northern Irish politicians, plus eight Scottish and ten Northern Irish civil servants. Wales was excluded because it lacks devolved competence for social security, there are no current proposals for and the Welsh government has not advocated devolved competence. ${ }^{22}$ Politicians included eight unionists, nine nationalists and one member of a party neutral on the constitutional question, recruited purposively on the basis of current or recent committee roles of relevance to social security, other areas of the welfare state or the constitution. Civil servants were drawn from departments or directorates with responsibility for social security, other welfare services, equality or finance. Consequently, participants were well informed on the relevant issues and potentially in a position to play a part in decisions on the division of responsibility for social security or in shaping a future devolved approach. Semi-structured interviews were conducted, usually on a one-to-one basis at the interviewee's place of work, with a constant comparative/constructivist grounded method adopted for data analysis. ${ }^{23}$ While the empirical data reflects research participants' views at a particular point in time, the article necessarily examines the significance for social citizenship of subsequent events.

\section{THE EVOLUTION OF SOCIAL CITIZENSHIP: KEY DEVELOPMENTS IN THE CAMERON ERA}

Successive governments have sought to reshape the UK's social security system in accordance with their own ideology of social citizenship or vision for social justice. The Attlee government was strongly influenced by the emphasis of the "reluctant collectivist" Beveridge on partnership between citizen and state. Following the "rediscovery of poverty," the "democratic socialists" of subsequent Labour governments embarked on a more concerted effort to use the welfare state as a "means of engineering a more equal and fair society." The "New Right" after 1975 was driven by revived mistrust of the state and faith in the market combined with scepticism as to whether 'real' poverty could exist in the modern UK to put in place reforms that, over time, would significantly reduce generosity to claimants. ${ }^{24}$ After 1997, the 'third way' tempered emphasis on the individual's

\footnotetext{
${ }^{22}$ Government of Wales Act 2006 c32 sch 5; Commission on Devolution in Wales, Empowerment and responsibility: legislative powers to strengthen Wales (Cardiff: Commission on Devolution in Wales, 2013); Welsh Government, 'Evidence submitted by the Welsh Government to the Commission on Devolution in Wales' (Cardiff: Welsh Government, 2013)

${ }^{23}$ BG Glaser and AL Strauss, The discovery of grounded theory: strategies for qualitative research (New York: Aldine, 1967); K Charmaz, Constructing grounded theory: a practical guide through qualitative analysis (London: Sage, 2006)

${ }^{24} \mathrm{R}$ Lowe, The welfare state in Britain since 1945 (London: Macmillan, 1999) 17-24; see also J Mack and S Lansley, Poor Britain (London: George Allen and Unwin, 1985); P Pierson, Dismantling the welfare state? Regan, Thatcher and the politics of retrenchment (Cambridge: Cambridge University Press, 1994)
} 
This is the peer reviewed version of the following article:

M Simpson, 'Renegotiating social citizenship in the age of devolution' (2017) 44(4) Journal of Law and Society 646

It has been published in final form at

http://onlinelibrary.wiley.com.proxy1.athensams.net/doi/10.1111/iols.12061/full. This article may be used for non-commercial purposes in accordance with Wiley Terms and Conditions for Self-

Archiving.

responsibility to meet his or her own needs through paid work with recognition that a "quiet redistribution" was necessary to protect some 'deserving' groups, notably children, from poverty. ${ }^{25}$

The Cameron governments oversaw a further ramping-up of emphasis on paid work alongside a reversal of the increases in generosity of 1997 to 2010. The self-imposed imperative of reducing the public deficit is not in itself sufficient explanation, as neither all areas of the welfare state nor all social groups were equally affected by spending cuts. ${ }^{26}$ While early policy documents foreground apparently pragmatic goals of simplicity, efficiency, "fewer layers of bureaucracy," "making work pay" and "tackling the root causes of poverty," ${ }^{27}$ subsequent developments and Ministers' statements reveal a particular understanding of the nature of poverty and the poor that must form part of the explanation. ${ }^{28}$ Although the coalition initially endorsed New Labour's child poverty reduction targets, its promise of "a new approach to child poverty" ${ }^{29}$ would birth a deprioritisation of income poverty through repeal of the statutory duties in the Child Poverty Act 2010. These developments embody a shift in the construction of poverty from a condition primarily characterised by lack of income to one mainly characterised by lack of employment. From the perspective of the then-Secretary of State, social transfers merely manage the "symptoms" of poverty; the "cause" can only be treated by employment ${ }^{30}$ - a position at odds with the finding that a near-exclusive focus on employment as the route out of poverty was incompatible with the achievement of the child poverty targets. ${ }^{31}$ However, this pragmatic explanation for the period's approach to social security is reinforced by a moral perspective according to which "those who do the right thing, who take a full time job" should be rewarded; ${ }^{32}$ those allegedly content to pass their days "sleeping off a life on benefits" should not be indulged. ${ }^{33}$

The reforms of 2010 to 2016 tended to reduce the generosity of the social security system. Although the flagship replacement of a suite of benefits with universal credit was intended to be revenue

\footnotetext{
${ }^{25} \mathrm{R}$ Lister, 'Doing good by stealth: the politics of poverty and inequality under New Labour' (2001) 8(2) New Economy 65; see also M Adler, 'Combining welfare-to-work measures with tax credits: a new hybrid approach to social security in the United Kingdom' (2004) 57(2) International Social Security Review 87

${ }^{26} \mathrm{~N}$ Ellison, 'The coalition government, public spending and social policy' in $\mathrm{H}$ Bochel and M Powell (eds), The coalition government and social policy: restructuring the welfare state (Bristol: Policy Press, 2016)

${ }^{27}$ Department for Work and Pensions, $21^{\text {st }}$ century welfare (Cm 7913, London: DWP, 2010) 1

$28 \mathrm{~J}$ Wiggan, 'Telling stories of $21^{\text {st }}$ century welfare: the UK coalition government and the neoliberal discourse of worklessness and dependency' (2012) 32(3) Critical Social Policy 383; C Pantazis, 'Policies and discourses of poverty during a time of recession and austerity' (2016) 36(1) Critical Social Policy 3

${ }^{29} \mathrm{HM}$ Government, $A$ new approach to child poverty: tackling the causes of disadvantage and transforming families' lives (Cm 8061, London: DWP, 2011)

${ }^{30} \mathrm{HM}$ Government, $A$ new approach to child poverty: tackling the causes of disadvantage and transforming families' lives (Cm 8061, London: DWP, 2011) 3

${ }^{31} \mathrm{H}$ Reed and J Portes, Understanding the parental employment scenarios necessary to meet the 2020 Child Poverty Targets (London: Social Mobility and Child Poverty Commission, 2014); see also R Joyce, 'Child poverty in Britain: recent trends and future prospects' (W15/07, London: IFS, 2014)

${ }^{32}$ I Duncan Smith, 'Foreword - Secretary of State for Work and Pensions' in HM Government, A new approach to child poverty: tackling the causes of disadvantage and transforming families' lives (Cm 8061, London: DWP, 2011) 3

${ }^{33}$ G Osborne, speech (Conservative Party conference, Birmingham, October 2012)
} 
This is the peer reviewed version of the following article:

M Simpson, 'Renegotiating social citizenship in the age of devolution' (2017) 44(4) Journal of Law and Society 646

It has been published in final form at

http://onlinelibrary.wiley.com.proxy1.athensams.net/doi/10.1111/iols.12061/full. This article may be used for non-commercial purposes in accordance with Wiley Terms and Conditions for Self-

Archiving.

neutral, the real or cash value of benefits was reduced by the new household benefit cap, ${ }^{34}$ reduction of the local housing allowance, ${ }^{35}$ extension of the housing benefit size criteria to social tenants, ${ }^{36}$ below-inflation uprating and ultimate freezing of income replacement benefits ${ }^{37}$ and twochild limit on the child element of universal credit and tax credits. ${ }^{38}$ The replacement of disability living allowance with the personal independence payment brought more restrictive eligibility criteria, ${ }^{39}$ eligibility periods for contributory employment and support allowance were shortened ${ }^{40}$ and jobseeker's allowance claimants were made subject to tougher conditions, with stiffer penalties for non-compliance. ${ }^{41}$

In parallel to this reshaping of social citizenship by the UK government came a partial renegotiation of the roles of the various tiers of government in the definition and realisation of citizens' social rights. Social security represents a rare field of social policy in which central government had retained its predominance after $1998 .{ }^{42}$ Centralised control began to erode under the coalition, in part led by the UK government's abolition of the discretionary social fund and council tax benefit, and devolution of responsibility for their replacements. ${ }^{43}$ Demand for regional control of other benefits came from below, with the Northern Ireland Assembly debating the most significant departures yet from provision in Great Britain ${ }^{44}$ and Scotland's main political parties advocating partial devolution of competence following the 2014 independence referendum. ${ }^{45}$

Dissatisfaction with the coalition's welfare reform agenda was not confined to the devolved regions, ${ }^{46}$ but parties in the devolved administrations were vocal critics. Scotland's Deputy First Minister warned that "the UK government's pernicious welfare reforms" would drive a significant increase in "the number of Scottish children living in poverty." ${ }^{47}$ At the introduction of Northern Ireland's Welfare Reform Bill, the chair of the Assembly scrutiny committee called for colleagues to "stand up for low income families" by making "fundamental changes" to a draft modelled on the

\footnotetext{
${ }^{34}$ Benefit Cap (Housing Benefit) Regulations 2012 no 2994 reg 2; Welfare Reform and Work Act 2016 c7 s8

${ }^{35}$ Rent Officers (Housing Benefit Functions) Order 1997 no 1984 art 4B

${ }^{36}$ Housing Benefit Regulations 2006 no 213 part 3

${ }^{37}$ Welfare Benefits Up-rating Act 2013 c16; Welfare Reform and Work Act 2016 c7 s11

${ }^{38}$ Welfare Reform and Work Act 2016 c7 s14

${ }^{39} \mathrm{~N}$ Harris, 'Welfare reform and the shifting threshold of support for disabled people' (2014) 77(6) Modern Law Review 888

${ }^{40}$ Welfare Reform Act 2012 c5 s51

${ }^{41}$ Jobseeker's Allowance (Sanctions) (Amendment) Regulations 2012 no 2568 reg 2

42 D Birrell, The impact of devolution on social policy (Bristol: Policy Press, 2009)

${ }^{43}$ Welfare Reform Act 2012 c5 s33, 70

${ }^{44}$ M Simpson, 'Developing constitutional principles through firefighting: social security parity in Northern Ireland (2015) 22(1) Journal of Social Security Law 31

${ }^{45}$ Smith Commission, Report of the Smith Commission for further devolution of powers to the Scottish Parliament (Edinburgh: Smith Commission, 2014)

${ }^{46}$ C Wood, 'Battling it out on welfare' (Public Finance, 27 January 2012) 11; J McDonnell, HC deb 20 July 2015 vol 598 no 36 col 1314

${ }^{47} \mathrm{~N}$ Sturgeon, 'Foreword from the Deputy First Minister' in Scottish Government, Child poverty strategy for Scotland: our approach 2014-2017 (Edinburgh: Scottish Government, 2014) 3
} 
This is the peer reviewed version of the following article:

M Simpson, 'Renegotiating social citizenship in the age of devolution' (2017) 44(4) Journal of Law and Society 646

It has been published in final form at

http://onlinelibrary.wiley.com.proxy1.athensams.net/doi/10.1111/iols.12061/full. This article may be used for non-commercial purposes in accordance with Wiley Terms and Conditions for SelfArchiving.

recent Westminster Act. ${ }^{48}$ In Wales, the Tackling Poverty Minister claimed the UK government was "coming for ordinary Welsh people... stepping away from their responsibility to the most vulnerable in our society. ${ }^{\prime 49}$ The inseparability of a hesitant process of decentralisation from reactions to the coalition programme will become apparent over subsequent sections.

\section{4. 'THE LIFE OF A CIVILISED BEING': AN ELUSIVE CONSENSUS ON A MINIMUM STANDARD OF LIVING}

Defining a minimum acceptable standard of living is no straightforward task. As Marshall emphasises, what "the life of a civilised being" looks like at a given time can only be understood with reference to "the standards prevailing." ${ }^{50}$ Although it is clear that the basic requirements of a normal lifestyle in the UK in 2016 include things that previous generations would have considered unimaginable luxuries, ${ }^{51}$ different perspectives exist on what those basic requirements are or what income is required to access them. While DWP's relative poverty line at 60 per cent of median income was based on the premise that the poorest households should not fall so far behind the "typical" household that they are unable to "take a full part in the activities that social inclusion demands," ${ }^{12}$ it is possible to argue that income-based poverty lines are "wholly arbitrary." 53

Arbitrary or not, the former statutory duty on the government to reduce child poverty according to the income standards enshrined in the 2010 Act was in keeping with Marshall's view that "the relief of the poor... is among the unqualified objects of public duty" 54 and with the right in article 11 ICESCR and article 27 UNCRC to an adequate standard of living. By its own standard, the UK government failed to discharge this 'unqualified duty': an interim target for the halving of child poverty between 1998-99 and 2010-11 was missed ${ }^{55}$ and even before their repeal it was apparent that the targets for 2020-21 would not be achieved..$^{56}$ The UK also falls short of international standards for poverty alleviation, benefit levels being "manifestly inadequate" to comply with article $12 \mathrm{ESC}$ (the right to social security) in $2014 .{ }^{57}$ The conclusion the same year that the state did comply with article 13 (the right to social assistance) was questionable then and becomes increasingly

\footnotetext{
${ }^{48}$ A Maskey, 'Sinn Féin calls for deferral of the Welfare Reform Bill' (Sinn Féin, 4 October 2012) <http://www.sinnfein.ie/contents/24642>

${ }^{49}$ B Powys, 'Benefit changes devastating - Welsh Minister Huw Lewis' (BBC News, 1 April 2013) <http://www.bbc.co.uk/news/uk-wales-politics-21988839>

${ }^{50}$ TH Marshall, 'Citizenship and social class' in TH Marshall and T Bottomore, Citizenship and Social Class (London: Pluto, 1992) 8

${ }^{51}$ D Nastic, 'Why we need a relative income poverty measure' (2012) 143 Poverty 13

52 Department for Work and Pensions, Measuring child poverty (London: DWP, 2003) 10

${ }^{53} \mathrm{C}$ Garroway and JR de Laiglesia, 'On the relevance of relative poverty for developing countries' (WP314, Issyles-Moulineaux: OECD Development Centre, 2012) 15

${ }^{54} \mathrm{TH}$ Marshall, 'The right to welfare' in The right to welfare and other essays (London: Heinemann, 1981) 84, 90

${ }^{55}$ Department for Work and Pensions and Department for Education, Child poverty in the UK: the report on the 2010 target (London: HMSO, 2012)

${ }^{56} \mathrm{M}$ Brewer, J Browne and R Joyce, Child and working age poverty from 2010 to 2020 (London: IFS, 2011)

${ }^{57}$ European Committee of Social Rights, European Social Charter: conclusions XX-2 (2013) (Great Britain)

(Strasbourg: Council of Europe, 2014) 18
} 
This is the peer reviewed version of the following article:

M Simpson, 'Renegotiating social citizenship in the age of devolution' (2017) 44(4) Journal of Law and Society 646

It has been published in final form at

http://onlinelibrary.wiley.com.proxy1.athensams.net/doi/10.1111/iols.12061/full. This article may be used for non-commercial purposes in accordance with Wiley Terms and Conditions for Self-

Archiving.

indefensible as benefits fall further behind earnings. Income from social assistance should be "not manifestly below" 50 per cent of median income, ${ }^{58}$ but even before the current freeze on income replacement benefits a childless couple on jobseeker's allowance could expect an income after housing costs no higher than 29 per cent of the equivalised median. ${ }^{59}$

\section{(a) Scotland}

A core element of Scottish elites' critique of the coalition was that poverty reduction remained a higher priority in their region than among a London-centric UK elite. That Scotland is "more socialist" (several politicians) in its outlook than England is hardly a novel assertion. ${ }^{60}$ Even if most studies conclude that the ideological gap is narrow at societal level, ${ }^{61}$ Scotland's party political centre of gravity is unquestionably to the left of England's and campaigners frequently portrayed independence as an opportunity to put (to use a phrase usually associated with Wales) ${ }^{62}$ "clear red water" between Scotland and the remainder of the UK. ${ }^{63}$ Scottish participants, while anxious not to overstate ideological differences with the north of England in particular, argued that "egalitarianism" (four interviewees), a concern for the "common weal" (politician) and an aspiration to "be a fairer country," albeit in a way that is "not absolutely defined" (politician), are central to the Scottish psyche and to Holyrood politics in a way that does not apply at Westminster today.

Whether this translates into a view that the state should be more generous in the standard of living it supports for citizens is less clear, at least where out-of-work benefits are concerned. Although there was near-universal agreement that the minimum wage was inadequate, there was no clear indication that out-of-work benefits would be higher if competence were devolved. Nor did any interviewee voice support for the Expert Working Group's suggestion that an independent Scotland might move towards a more contributory, conservative model of social security, ${ }^{64}$ which might be expected to be more generous towards the short term unemployed. This may in part reflect the timing of the interviews in the immediate aftermath of a command paper indicating that the rates of the main income replacement benefits would not be among the devolved social security competences. ${ }^{65}$ However, even in the current context of greater clarity that Scotland has the option

\footnotetext{
${ }^{58}$ European Committee of Social Rights, European Social Charter: conclusions XX-2 (2013) (Great Britain) (Strasbourg: Council of Europe, 2014) 22

${ }^{59}$ Author's calculation based on J Shale, K Balchin, J Rahman, R Reeve and M Rolin, Households below average income: an analysis of the income distribution 1994/95-2013/14 (London: DWP, 2015)

${ }^{60}$ See G Mooney and L Poole, “'A land of milk and honey”? Social policy in Scotland after devolution' (2004) 24(4) Critical Social Policy 458; N McEwen, 'The territorial politics of social policy development in multilevel states' (2005) 15(4) Regional and Federal Studies 537

$61 \mathrm{~J}$ Curtice and R Ormston, 'Is Scotland more left-wing than England?' (Edinburgh: ScotCen Social Research, 2011); J Mitchell, The Scottish question (Oxford: Oxford University Press, 2014)

62 DS Moon, 'Rhetoric and policy learning: on Rhodri Morgan's "clear red water" and "made in Wales" health policies' (2012) 28(3) Public Policy and Administration 306

63 G Mooney and G Scott, 'The 2014 Scottish independence debate: questions of social welfare and social justice' (2015) 23(1) Journal of Poverty and Social Justice 5

${ }^{64}$ Expert Working Group on Welfare, Re-thinking welfare: fair, personal and simple (Edinburgh: Scottish Government, 2014)

${ }^{65} \mathrm{HM}$ Government, Scotland in the United Kingdom: an enduring settlement ( $\mathrm{Cm}$ 8990, Edinburgh: Scotland Office, 2015)
} 
This is the peer reviewed version of the following article:

M Simpson, 'Renegotiating social citizenship in the age of devolution' (2017) 44(4) Journal of Law and Society 646

It has been published in final form at

http://onlinelibrary.wiley.com.proxy1.athensams.net/doi/10.1111/iols.12061/full. This article may be used for non-commercial purposes in accordance with Wiley Terms and Conditions for Self-

Archiving.

of topping up reserved benefits, ${ }^{66}$ there are no proposals to use this power. ${ }^{67}$ Pressure to make topups may increase if, as proposed, the former child poverty reduction duty is reinstated in Scotland:68 despite emphasis from all tiers of government on employment as the best route out of poverty, progress towards the targets under New Labour was closely associated with increases in the real value of benefits. ${ }^{69}$

Greater generosity has always been more likely in respect of housing-related benefits, which will come under Holyrood's control. ${ }^{70}$ Following the Welfare Reform Act 2012 the Scottish government undertook to make good any reduction of social tenants' housing benefit due to under-occupancy, ${ }^{71}$ and it now states that no under-occupancy penalty will apply to them under universal credit. ${ }^{72}$ Interviewees endorsed this approach on pragmatic grounds, under-occupation being relatively widespread in Scotland, ${ }^{73}$ and ideological grounds, with Scots claimed to be more inclined to view a social rental as a "home for life" (politician). There was widespread resistance to the introduction of PIP, which will see fewer individuals have any entitlement compared to disability living allowance and reduced payments for many others. ${ }^{74}$ Here, appetite for a Scotland-specific disability benefit recommended by the Expert Working Group and hinted at in early Scottish government proposals ${ }^{75}$ - was greater, with various interviewees suggesting this might widen eligibility, but not necessarily increase generosity at the individual level. However, current proposals are for administrative changes only, notably to the (re)assessment process, with no hint of radical change in eligibility criteria and higher payments proposed in respect of carer's allowance only. ${ }^{76}$ Increased generosity is found in the Scottish welfare fund, which replaces the discretionary social fund's crisis loans with non-repayable grants. ${ }^{77}$

Social security devolution in Scotland is in its infancy. Already there are some - albeit few indications that devolved areas of the system to will be more generous than their equivalents in

\footnotetext{
${ }^{66}$ Scotland Act 2016 c11 s24

${ }^{67}$ See Scottish Government, A new future for social security: consultation on social security in Scotland (Edinburgh: Scottish Government, 2016)

${ }^{68}$ Child Poverty (Scotland) SP Bill (2016-17) [6]

${ }^{69} \mathrm{R}$ Joyce, 'Child poverty in Britain: recent trends and future prospects' (W15/07, London: IFS, 2014); see also

$R$ Lister, 'Doing good by stealth: the politics of poverty and inequality under New Labour' (2001) 8(2) New

Economy 65

${ }^{70}$ Scotland Act 2016 c11 s29

${ }^{71}$ Discretionary Housing Payments (Limit on Total Expenditure) Revocation (Scotland) Order 2014 no 298; K Berry, Discretionary housing payments (SPICe briefing 14/17, Edinburgh: Scottish Parliament, 2014)

${ }^{72}$ Scottish Government, $A$ new future for social security: consultation on social security in Scotland (Edinburgh: Scottish Government, 2016)

${ }^{73} \mathrm{~K}$ Gibb, The 'bedroom tax' in Scotland (SP paper 409, Edinburgh: Scottish Parliament, 2013)

${ }^{74} \mathrm{~N}$ Harris, 'Welfare reform and the shifting threshold of support for disabled people' (2014) 77(7) Modern Law Review 888

${ }^{75}$ Expert Working Group on Welfare, Re-thinking welfare: fair, personal and simple (Edinburgh: Scottish Government, 2014); Scottish Government, Creating a fairer Scotland: a new future for social security in Scotland (Edinburgh: Scottish Government, 2016)

${ }^{76}$ Scottish Government, $A$ new future for social security: consultation on social security in Scotland (Edinburgh: Scottish Government, 2016)

${ }_{77}$ Welfare Funds (Scotland) Regulations 2016 no 107
} 
This is the peer reviewed version of the following article:

M Simpson, 'Renegotiating social citizenship in the age of devolution' (2017) 44(4) Journal of Law and Society 646

It has been published in final form at

http://onlinelibrary.wiley.com.proxy1.athensams.net/doi/10.1111/iols.12061/full. This article may be used for non-commercial purposes in accordance with Wiley Terms and Conditions for SelfArchiving.

England and Wales. Unionist interviewees who argued that while in the run-up to the referendum nationalists were quick to imply benefits would be higher following independence, "at no point did they suggest that it was possible to have a higher budget for that area of policy" may feel their scepticism vindicated. An alternative perspective might hold, as civil servants argued, that it would be unrealistic to expect radical change immediately upon devolution. Important questions about budgeting, ${ }^{78}$ policy development, system oversight, interaction with reserved benefits ${ }^{79}$ and what the pledge to develop an approach underpinned by the principles of dignity and respect means in practice $^{80}$ must be resolved before a genuinely Scottish model can emerge. Which point of view is closer to the truth will become clear over time.

\section{(b) Northern Ireland}

Social security has been devolved to Northern Ireland since 1921, in principle creating greater opportunity to develop a more distinctive approach than in Scotland even after the 2016 Act. However, policy since then has been characterised by a strict adherence to parity with Great Britain. While opportunities for radicalism have been tempered by economics and a politically disunited Executive capable of agreeing a "lowest common denominator" only on the basis of shared conservative social values and protection of the "unambiguously deserving poor," ${ }^{81}$ recent rhetoric demands consideration of whether full autonomy would result in more generous provision.

The story of Northern Ireland's Welfare Reform Bill illustrates the difficulties associated with striking agreement within the consociational Executive. A critical committee report on a Bill authored to replicate the 2012 Act was followed by two years of negotiations on the extent of divergence affordable, apparent agreement on a package of mitigations and last-gasp defeat of the Bill at the final legislative stage.$^{82}$ The mitigations proposed alongside the Welfare Reform (NI) Order 2015 and Welfare Reform and Work (NI) Order 2016, ${ }^{83}$ the vehicles by which the 2012 and 2016 reforms are being extended to the region, do suggest an ability to unite around protection of the "unambiguously deserving poor," ${ }^{84}$ with an additional focus on victims of the conflict of the 1960 s to

\footnotetext{
${ }^{78} \mathrm{D}$ Birrell and AM Gray, 'Welfare reform and devolution: issues of parity, discretion and divergence for the UK government and the devolved administrations' (2014) 34(3) Public Money and Management 205

${ }^{79} \mathrm{G}$ McKeever, 'Legislative scrutiny, coordination and the role of the Social Security Advisory Committee: from system coherence to Scottish devolution' (2016) 23(3) Journal of Social Security Law 126

${ }^{80} \mathrm{M}$ Simpson, G McKeever and AM Gray, Social security systems based on dignity and respect (Glasgow: EHRC, 2017 - forthcoming)

${ }^{81}$ E McLaughlin, 'Governance and social policy in Northern Ireland (1999-2002): the devolution years and postscript', in M Powell, L Bauld and J Clarke (eds), Social Policy Review 17, Analysis and Debate in Social Policy (Bristol: Policy Press, 2005) 107; AM Gray and D Birrell, 'Coalition government in Northern Ireland: social policy and the lowest common denominator thesis' (2012) 11(1) Social Policy and Society 15

${ }^{82}$ Committee for Social Development, Report on the Welfare Reform Bill (NIA Bill 13/11-15) (NIA74/11-15, Belfast: NI Assembly, 2013); Northern Ireland Office, Stormont House Agreement (Belfast: NIO, 2014); NIA deb 26 May 2015, vol 105 no 1

${ }^{83}$ Welfare Reform Mitigations Working Group, Welfare Reform Mitigations Working Group Report (Belfast: OFMDFM, 2016)

${ }^{84}$ E McLaughlin, 'Governance and social policy in Northern Ireland (1999-2002): the devolution years and postscript', in M Powell, L Bauld and J Clarke (eds), Social Policy Review 17, Analysis and Debate in Social Policy (Bristol: Policy Press, 2005) 107
} 
This is the peer reviewed version of the following article:

M Simpson, 'Renegotiating social citizenship in the age of devolution' (2017) 44(4) Journal of Law and Society 646

It has been published in final form at

http://onlinelibrary.wiley.com.proxy1.athensams.net/doi/10.1111/iols.12061/full. This article may be used for non-commercial purposes in accordance with Wiley Terms and Conditions for SelfArchiving.

1990s and a dash of policy learning from Scotland. ${ }^{85}$ Hence, for a transitional period, there will be compensation for disabled people and carers who lose income; people with conflict-related disabilities ineligible for PIP; families with children affected by the household benefit cap; and social tenants affect by the size criteria. ${ }^{86}$

Pragmatic reasons for more generous social security exist in Northern Ireland: with high levels of disability and economic inactivity, citizens and economy are more dependent on benefits than the UK average. With social tenants also disproportionately likely to under-occupy, ${ }^{87}$ the projected per capita economic impact of reforms up to 2013 was 23 per cent greater than the worst affected region in Great Britain. ${ }^{88}$ Not all interviewees depicted Northern Ireland as a 'special case': two politicians simply felt the opportunity presented by devolution to diverge from reform "that isn't working in Britain" should not be passed up. However, most focused on the particular circumstances of the region in their critique of coalition policy, arguing that high energy costs, economic weakness following decades of conflict, a peripheral location and treatment as a "backwater" (politician) by successive UK administrations could only magnify the effect of benefit cuts. Even sceptics as to the merits of widespread divergence advocated some special treatment on the grounds of the legacy of the 'troubles', albeit that others considered that "20-odd years after the ceasefires... you must be a little bit less special than what you were" (politician). Ongoing social division in the post-conflict era was depicted as a decisive argument against the reduction of housing benefit for under-occupying social tenants, given that ethno-religious segregation in social housing further limits tenants' ability to move to scarce smaller accommodation. On the other hand, a small number of civil servants suggested Northern Ireland's circumstances justified "cutting back on benefits to encourage people into work" to a greater extent than in Great Britain, a single UK rate being more likely to "act as a drag for the labour market" in a region with below-average earnings.

Ultimately, despite devolved competence for social security, Northern Ireland's freedom to manoeuvre is constrained. Adherence to parity with Great Britain reflects not only the view that citizens of a single state ought to enjoy comparable social provision, which retained support among unionists and civil servants, but also fear of the budgetary impact of paying and administering more generous benefits. A recent Minister's claim that the region is required to maintain parity in headline rates of benefits ${ }^{89}$ is legally questionable -the legislation states only that when the Secretary of State uprates benefits the Northern Ireland Minister "may make a corresponding order." ${ }^{90}$ However, given

\footnotetext{
${ }^{85}$ M Simpson, 'The social union after the coalition: devolution, divergence and convergence' (2017) 46(2) Journal of Social Policy 251

${ }^{86}$ Welfare Supplementary Payments Regulations (Northern Ireland) 2016 no 178; Welfare Supplementary Payment (Loss of Carers Benefit) Regulations (Northern Ireland) 2016 no 253; Welfare Supplementary Payment (Benefit Cap) Regulations (Northern Ireland) 2016 no 389; Welfare Supplementary Payment (Amendment) Regulations (Northern Ireland) 2017 (draft); Housing Benefit (Welfare Supplementary Payment) Regulations (Northern Ireland) 2017 (draft)

${ }^{87} \mathrm{~K}$ Gibb, The 'bedroom tax' in Scotland (SP paper 409, Edinburgh: Scottish Parliament, 2013)

${ }^{88} \mathrm{C}$ Beatty and S Fothergill, The impact of welfare reform on Northern Ireland (Sheffield: Centre for Economic Empowerment, 2013)

${ }^{89}$ M Storey, NIA deb 27 Apr 2015 vol 103 no 3 p2

${ }^{90}$ Social Security Administration (Northern Ireland) Act 1992 c8 s132
} 
This is the peer reviewed version of the following article:

M Simpson, 'Renegotiating social citizenship in the age of devolution' (2017) 44(4) Journal of Law and Society 646

It has been published in final form at

http://onlinelibrary.wiley.com.proxy1.athensams.net/doi/10.1111/jols.12061/full. This article may be used for non-commercial purposes in accordance with Wiley Terms and Conditions for SelfArchiving.

the controversy that surrounded the affordability of a limited set of mitigations, it can be assumed that the far costlier step of uprating benefits faster than in Great Britain would be politically difficult. ${ }^{91}$

\section{THE RIGHTS AND RESPONSIBILITIES OF CITIZENSHIP: STRIKING} THE RIGHT BALANCE

One of the more controversial aspects of Marshall's vision of social citizenship is the balance between the citizen's right to support and reciprocal responsibilities to society. Marshall's characterisation of financial support when required as a "moral right"92 has birthed the critique that his is no more than a "theory of entitlement," ${ }^{13}$ yet it is far from clear that he advocates "unconditional entitlement to welfare." ${ }^{94}$ Powell and Hewitt set Marshall, the supposed advocate of largely unconditional welfare services, against Beveridge, for whom entitlement should be primarily based on previous contribution and claimants must "use their time, so as to fit themselves or to keep themselves fit for service" ${ }^{\prime 95}$ - in today's language, welfare-to-work. Yet Marshall speaks approvingly of Beveridge's efforts to establish a "new social order" (albeit with certain "defects") ${ }^{96}$ and argues that the moral right to welfare can be satisfied by an appropriately administered discretionary safety net, even if a legal right is not strictly present ${ }^{97}$ Similarly, the Marshallian model of citizenship includes a moral duty, although not necessarily a legal duty, to work as a "responsibility towards the welfare of the community."

The UK state has never accepted an unconditional right to income, housing and other essentials (healthcare and education are perhaps exceptions). Paid employment is constructed as the "only route to social mobility and... the sole means of acquiring the status and rights of citizenship" contributing to society. Social citizenship becomes:

\footnotetext{
${ }^{91}$ For the observation that curbs on uprating under the coalition saved much more money than measures that generated much more media attention, see S McKay and K Rowlingson, 'Social security under the coalition and Conservatives: shredding the system for people of working age; privileging pensioners' in $\mathrm{H}$ Bochel and $\mathrm{M}$ Powell, The coalition government and social policy: restructuring the welfare state (Bristol: Policy Press, 2016)

92 TH Marshall, 'The right to welfare' in The right to welfare and other essays (London: Heinemann, 1981) 90

93 BS Turner and C Rojek, Society and culture: principles of scarcity and solidarity (London: Sage, 2001) 202

94 P Dwyer, 'Creeping conditionality in the UK: from welfare rights to conditional entitlements?' (2004) 29(2) Canadian Journal of Sociology 265

${ }^{95}$ W Beveridge, Social insurance and allied services (Cmd 6404, London: HMSO, 1942) para 23; see M Powell, 'The hidden history of social citizenship' (2002) 6(3) Citizenship Studies 229

96 TH Marshall, Social policy (London: Hutchinson, 1975) 83, 90

97 TH Marshall, 'The right to welfare' (1965) 13(3) Sociological Review 261

98 TH Marshall, Class, citizenship, and social development: essays (Westport, CT: Greenwood Press, 1977) 117; TH Marshall, 'Citizenship and social class' in TH Marshall and T Bottomore, Citizenship and Social Class (London: Pluto, 1992) 16, 41, 45

${ }^{99}$ PM Larkin, 'The legislative arrival and future of workfare: the Welfare Reform Act 2009' (2011) 18(1) Journal of Social Security Law 11, 17
} 
This is the peer reviewed version of the following article:

M Simpson, 'Renegotiating social citizenship in the age of devolution' (2017) 44(4) Journal of Law and Society 646

It has been published in final form at

http://onlinelibrary.wiley.com.proxy1.athensams.net/doi/10.1111/iols.12061/full. This article may be used for non-commercial purposes in accordance with Wiley Terms and Conditions for SelfArchiving.

"an achievement rather than a status... Individuals do not and cannot have a right to the resources of society unless they contribute to the development of that society through work or other socially valued activities, if they are in a position to do so."100

The first Beveridgean manifestation of work-related reciprocity - contribution - has been lauded as the ideal basis for social security, yet seemingly in permanent decline, since before the foundation of the modern welfare state. ${ }^{101}$ The insurance principle retains advocates in the $21^{\text {st }}$ century, ${ }^{102}$ yet its relevance to working age benefits continues to decrease. ${ }^{103}$ The second - efforts to enter or return to paid work - has become increasingly entrenched. ${ }^{104}$ Unemployed claimants must participate in interventions - from interviews with an adviser to unpaid placements - to improve employment prospects, ${ }^{105}$ with non-compliance meaning exposure to financial sanctions that have been stiffened, to a maximum of three years' loss of benefit, and whose use has escalated since $2007 .{ }^{106}$ The number of claimants excused from jobseeking conditionality on the basis of ill health, age or engagement in "other socially valued activities" has shrunk, with lone parents, recipients of incapacity benefits, people aged over 65 and carers increasingly drawn into the activation pool.

Beveridge assumed married women would spend most of their time on the "vital work" of raising children and supporting their husbands, who in return would ensure their wives' economic welfare. ${ }^{107}$ The priority afforded to caregiving was also reflected in lone parents' unconditional eligibility for social assistance from the 1940 s until the start of the $21^{\text {st }}$ century ${ }^{108}$ and in the creation of a dedicated benefit for full-time carers for disabled people. ${ }^{109}$ Increasing emphasis on labour market engagement as the preferred basis of entitlement is embodied in the introduction of joint

\footnotetext{
${ }^{100}$ R Plant, 'Supply side citizenship?' (1999) 6(3) Journal of Social Security Law 124, 125

${ }^{101}$ TH Marshall, Social policy (London: Hutchinson, 1975) 66, 72

102 P Saunders, Beyond Beveridge: restoring the contributory principle to retirement pensions and welfare benefits (London: Civitas, 2013); D O'Leary, 'Something for something: restoring a contributory principle to the welfare state' (London: Demos, 2013)

${ }^{103}$ Social Security Committee, The contributory principle (HC 51-I, London: House of Commons, 2000); I Clasen, 'Social insurance and the contributory principle: a paradox in contemporary British social policy' (2001) 35(6) Social Policy and Administration 641

${ }^{104}$ EZ Brodkin and F Larsen, 'The policies of workfare: at the boundaries between work and the welfare state' in EZ Brodkin and G Marston (eds), Work and the welfare state: street level organisations and workfare policies (Washington DC: Georgetown University Press, 2013)

${ }^{105}$ See N Harris, 'From unemployment to active jobseeking: changes and continuities in social security law in the United Kingdom' in S Stendahl, T Erhag and S Devetzi (eds). A European work-first welfare state (Gothenburg: Centre for European Research, 2008); PM Larkin, 'The legislative arrival and future of workfare: the Welfare Reform Act 2009' (2011) 18(1) Journal of Social Security Law 11

106 Jobseeker's Allowance (Sanctions) (Amendment) Regulations 2012 no 2568 reg 2; Universal Credit Regulations 2013 no 376 reg 101-105; Jobseeker's Allowance Regulations 2013 no 378 reg 17-21; see M Adler, 'A new leviathan: benefit sanctions in the $21^{\text {st }}$ century' (2016) 43(2) Journal of Law and Society 195 ${ }^{107}$ W Beveridge, Social insurance and allied services (Cmd 6494, London: HMSO, 1942) para 108-117; W Beveridge, 'Sir William Beveridge announcement: Beveridge outlines his proposals for a new welfare state' (BBC Home Service, 2 December 1942) <http://www.bbc.co.uk/archive/nhs/5139.shtml> accessed 28 October 2015

${ }^{108}$ National Assistance Act 1948 c29 s5,6; Income Support (General) Regulations 1987 no 1967 sch 1

${ }^{109}$ Social Security (Invalid Care Allowance) Regulations 1976 no 409; Social Security Contributions and Benefits Act 1992 c4 s70
} 
This is the peer reviewed version of the following article:

M Simpson, 'Renegotiating social citizenship in the age of devolution' (2017) 44(4) Journal of Law and Society 646

It has been published in final form at

http://onlinelibrary.wiley.com.proxy1.athensams.net/doi/10.1111/iols.12061/full. This article may be used for non-commercial purposes in accordance with Wiley Terms and Conditions for Self-

Archiving.

claims for jobseeker's allowance from $1999^{110}$ and the rapid change in the treatment of lone parents since 2007, with transfer to JSA mandated at a progressively earlier stage in their children's lives (the third birthday following the Welfare Reform and Work Act 2016). Since carer's allowance is parasitic on disability benefits, the tightening of eligibility criteria inherent in PIP will result in fewer being eligible. ${ }^{111}$ Claimant activation has been a feature of incapacity-related benefits since the New Labour era. ${ }^{112}$ Reduction of the benefit payable to employment and support allowance claimants in the work related activity group to a level equivalent to $\mathrm{JSA}^{113}$ further emphasises the expectation that they will return to paid employment relatively quickly, even though in practice the typical ESA claim lasts significantly longer than the typical JSA claim -60 per cent of JSA claims last around six months, whereas 60 per cent of WRAG claimants remain in the group for two years. ${ }^{114}$

\section{(a) Rights and responsibilities in the devolved regions}

Legislators in Scotland and Northern Ireland have indicated dissatisfaction with the UK government's approach to claimant conditionality. A number of provisions relating to sanctions are included in the 'mitigations' proposed in Northern Ireland as it belatedly implements the reforms legislated for in Great Britain in 2012. Notably, the maximum period for which benefit may be withdrawn is capped at eighteen months, as opposed to 36 in Great Britain, and it is proposed that all sanctioned claimants should be referred to a dedicated helpline for advice on appeals, hardship payments and other matters. ${ }^{115}$ While Scotland's new competences exclude claimant conditionality, parliamentarians have issued a critical report on the post-2012 regime, ${ }^{116}$ the Scottish Welfare Fund extends eligibility for crisis grants to sanctioned claimants, who were ineligible for the social fund, ${ }^{117}$ and sanctions are being designed out of devolved employment support schemes. ${ }^{118}$ This raises the question of whether the disciplinary approach that increasingly characterises UK social security is in keeping with constructions of social citizenship in the devolved regions.

\footnotetext{
${ }^{110}$ Jobseekers Act 1995 c19 s2A-2D as amended by Welfare Reform and Pensions Act 1999 c30 s59; sch 7 para 2

${ }^{111}$ Carer's allowance is only payable if the person being cared for is in receipt of a qualifying disability benefit and at least 20 per cent of DLA claimants are projected to be ineligible for PIP - see N Harris, 'Welfare reform and the shifting threshold of support for disabled people' (2014) 77(7) Modern Law Review 888

112 K Puttick, 'Empowering the incapacitated worker? The employment and support allowance and Pathways to Work' (2007) 36(3) Industrial Law Journal 388; PM Larkin, 'Incapacity, the labour market and social security: coercion into "positive" citizenship' (2011) 74(3) Modern Law Review 385

${ }^{113}$ Welfare Reform and Work Act 2016 c7 s15-16

${ }^{114}$ Lord Low of Dalston, Baroness Meacher and Baroness Grey-Thompson, Halving the gap? A review into the government's proposed reduction to employment and support allowance and its impact on halving the disability employment gap (London: Mencap, 2015)

${ }^{115}$ Welfare Reform (Northern Ireland) Order 2015 no 2006 (NI 1) art 31; Welfare Reform Mitigations Working Group, Welfare Reform Mitigations Working Group Report (Belfast: OFMDFM, 2016)

${ }^{116}$ Welfare Reform Committee, Interim report on the new benefit sanctions regime: tough love or tough luck? (SP paper 552, Edinburgh: Scottish Parliament, 2014)

${ }^{117}$ Scottish Government, Draft Scottish Welfare Funds - guidance - to come into force April 2016 (Edinburgh:

Scottish Government, 2015)

${ }^{118}$ Social Security Committee, Official Report 2 February 2017
} 
This is the peer reviewed version of the following article:

M Simpson, 'Renegotiating social citizenship in the age of devolution' (2017) 44(4) Journal of Law and Society 646

It has been published in final form at

http://onlinelibrary.wiley.com.proxy1.athensams.net/doi/10.1111/iols.12061/full. This article may be used for non-commercial purposes in accordance with Wiley Terms and Conditions for Self-

Archiving.

If there are doubts about the UK government's methods, its objective of speeding the transition into and ensuring a financial reward for employment is endorsed at devolved level. ${ }^{119}$ Interview data show a broad consensus that "work is the best thing for people" (civil servant, Scotland) or "when somebody is out of work their job should be finding work" (civil servant, NI). Yet considerable differences of perspective emerge between Scotland and Northern Ireland, and there is a tendency for sympathy for individual claimants to sit alongside a more equivocal or supportive view of conditionality per se.

Various Scottish interviewees portrayed the post-2012 conditionality regime as little more than a policy of vindictiveness against people the state has chosen to construct as "a drag on society" (politician). Even those taking the more charitable view that DWP "believe... if they make anything... less punitive you decrease the incentive to go to work, and ultimately that would be bad for the people themselves" (civil servant) tended to view policy as excessively harsh. Few suggested Scotland could or would operate a sanction-free unemployment benefit, but there was widespread agreement that penalties have become too severe and near-consensus that they are too readily imposed. Most politicians had a 'horror story' of a constituent who had been sanctioned for "spurious" reasons despite his or her best efforts to comply with conditions attached to a benefit. Examples included individuals who had missed appointments as a result of a genuine mistake or clash with a job interview, had not understood their obligations or had supplied insufficient documentary evidence of compliance. The implication was that there was nothing the claimant could have done to avoid the sanction, or that even if behaviour had been modified so as to avoid the sanction employment prospects would have been unaffected. ${ }^{120}$ Although one politician argued sanctions are necessary to force reluctant or disengaged claimants to engage with employment support, others were dismissive of the quality of this support. ${ }^{121}$

Ultimately, jobseekers' obligation to accept any job at any wage is at odds with most interviewees' vision of Scotland as a society in which employment remains key to economic welfare and an important contribution to society, ${ }^{122}$ but where "fair work," a living wage and job security are afforded higher priority. In place of a disciplinary UK welfare state whose aim is to "bully people into low paid work" (politician, Scotland), the dominant aspiration was to an enabling welfare state in which people are empowered and supported to enter rewarding employment. This vision for an enabling welfare state does not extend to enthusiasm for the market as a provider of welfare services - an element of New Labour's model of the enabling state ${ }^{123}$ from which Scotland has

\footnotetext{
${ }^{119}$ Committee for Social Development, Report on the Welfare Reform Bill (NIA Bill 13/11-15) (NIA 74/11-15, Belfast: Northern Ireland Assembly, 2013); Expert Working Group on Welfare, Re-thinking welfare: fair, personal and simple (Edinburgh: Scottish Government, 2014)

${ }^{120}$ A similar critique from claimants is reported in S Wright and ABR Stewart, 'First wave findings: jobseekers' (York: Welfare Conditionality, 2016) <http://www.welfareconditionality.ac.uk/wp-

content/uploads/2016/05/WelCond-findings-jobseekers-May16.pdf>

${ }^{121}$ See Work and Pensions Committee, Welfare-to-work (HC363, London: House of Commons, 2015)

122 See R Lister, Citizenship: feminist perspectives (Basingstoke: Palgrave Macmillan, 2003) 138

${ }^{123}$ T Burchardt and J Hills, 'Public expenditure and the public/private mix' in M Powell (ed), New Labour, new welfare state? (Bristol: Policy Press, 1999);
} 
This is the peer reviewed version of the following article:

M Simpson, 'Renegotiating social citizenship in the age of devolution' (2017) 44(4) Journal of Law and Society 646

It has been published in final form at

http://onlinelibrary.wiley.com.proxy1.athensams.net/doi/10.1111/iols.12061/full. This article may be used for non-commercial purposes in accordance with Wiley Terms and Conditions for Self-

Archiving.

tended to distance itself. ${ }^{124}$ So the Welsh model of contracting out delivery of discretionary assistance, a civil servant suggested, was not "considered to be appropriate in Scotland."

Interviewees' comments and some early proposals for devolved social security do align with other features of the enabling state. ${ }^{125}$ Social security devolution is itself an example of movement towards a localised state, but the Scottish government has gone further, devolving delivery of the Scottish welfare fund and (by necessity) mitigation of the social sector size criteria to local authorities. Even interviewees sceptical about social security devolution eagerly anticipated a key role for local government in the delivery of employment support, allowing greater responsiveness to local labour market needs. Devolution of employment support was also predicted to result in a move from a 'new public management' focus on short-term measures of success - getting people off benefits by any means, ${ }^{126}$ seen as DWP's goal - to a 'public value' approach emphasising sustainable employment. A clear desire existed to move from crisis intervention to crisis prevention, with politicians generally supportive of a higher minimum wage and less use of in-work benefits ("subsidies for employers who treat people badly"), more state provision or subsidisation of childcare and fewer parents on income support. ${ }^{127}$ Participative democracy and coproduction of policy were not mentioned during fieldwork, but are among the principles for the development of Scottish social security announced in 2016. ${ }^{128}$ More broadly, the shift from silos to integration embodied in the 2007 transformation of the Scottish government to a single, non-departmental entity ${ }^{129}$ was viewed by civil servants as one factor facilitating a shared commitment across government to social justice.

In Northern Ireland, there was greater buy-in to "the lain Duncan Smith view of the world" (civil servant), that the social security system had been "having a negative impact in terms of... social inclusion" and that a more interventionist approach was required to promote employment.

Although one civil servant argued that social security and employment support should be separated entirely - that "welfare's about looking after people's needs; getting them back to work is a different thing altogether" - this was a minority view. Indeed, the recent reorganisation of devolved government has brought the two functions within the remit of a single department (the Department for Communities), as in Great Britain (DWP). Most interviewees accepted that social protection should encourage, through coercion if necessary, labour market engagement. This could mean

\footnotetext{
${ }^{124} \mathrm{~N}$ McEwen, 'The territorial politics of social policy development in multilevel states' (2005) 15(4) Regional and Federal Studies 537; M Keating, 'Social citizenship, solidarity and welfare in regionalised and plurinational states' (2009) 13(5) Citizenship Studies 501

${ }^{125}$ See J Wallace, The rise of the enabling state: a review of policy and evidence across the UK and Ireland (Dunfermline: Carnegie Trust, 2013)

${ }^{126}$ See J Rees, A Whitworth and E Carter, 'Support for all in the UK work programme? Differential payments, same old problem...' (WP115, Birmingham: Third Sector Research Centre, 2013)

${ }^{127}$ See G Esping-Andersen, 'A welfare state for the $21^{\text {st }}$ century' in A Giddens (ed), The global third way debate (Cambridge: Polity Press, 2001)

${ }^{128}$ Scottish Government, $A$ new future for social security: consultation on social security in Scotland (Edinburgh: Scottish Government, 2016) 12

129 J Elvidge, 'Scottish public services are a force to be reckoned with' (Guardian, 13 December 2013) $<$ https://www.theguardian.com/public-leaders-network/2013/dec/13/scottish-government-redesigned-johnelvidge>
} 
This is the peer reviewed version of the following article:

M Simpson, 'Renegotiating social citizenship in the age of devolution' (2017) 44(4) Journal of Law and Society 646

It has been published in final form at

http://onlinelibrary.wiley.com.proxy1.athensams.net/doi/10.1111/iols.12061/full. This article may be used for non-commercial purposes in accordance with Wiley Terms and Conditions for Self-

Archiving.

keeping benefits low to motivate "people who don't want to work [because] if they were to get a job it may not be of the same level that they're getting on the welfare benefit system" (politician).

Equally, it could mean "some kind of stick" (civil servant) to punish reluctant jobseekers. Even the coalition's fiercest critics stressed: "There's no question of us countenancing people just sitting and not going to work and drawing on benefits" (politician).

Nonetheless Northern Ireland's conditionality regime will be less harsh than Great Britain's - if only in the "symbolic" (civil servant) halving of the duration of the heaviest possible sanction, which most interviewees believed would seldom be imposed - and provision is being made to ensure access to advice services for sanctioned claimants. Perhaps more significantly, sanctions are much less used in Northern Ireland, ${ }^{130}$ which civil servants there and in Scotland believed was due to administration of the system by a regional Social Security Agency, insulated from political pressure within DWP to treat claimants harshly. ${ }^{131}$ So while interviewees in Northern Ireland were generally comfortable with the use of disciplinary measures to enforce jobseeking, there was widespread concern that in Great Britain the potential severity and application of sanctions had become "unjust" (civil servant), with the region's approach representing a more proportionate model.

As in Scotland, there was concern that the activities in which claimants are compelled to take part are less than helpful in aiding the transition to employment. In the context of a regional labour market relatively lacking in opportunity, ${ }^{132}$ it was suggested, "some reality needs to kick in" (civil servant) on the part of advisers who require claimants to spend many hours per week seeking for jobs that, in the view of a number of interviewees, simply do not exist. Indeed, prescriptive jobseeking agreements backed up with the threat of sanction were portrayed by some as undermining "the relationship that's built between the adviser and the customer" (civil servant) ${ }^{133}$ and therefore prospects of transition to employment. With greater historic divergence in employment support than in social security, some civil servants proclaimed Northern Ireland's activation schemes superior to DWP's. However, an alternative perspective argued any approach that depends on private contractors will be compromised because "they'll always cherry pick the

\footnotetext{
${ }^{130}$ In 2014, the overall sanctioning rate in Northern Ireland was less than half and the higher level sanctioning rate just 14 per cent of that in Great Britain - author's calculation based on data from Department for Work and Pensions, 'Jobseeker's allowance and employment and support allowance sanctions statistics' (London: DWP, 2015) <https://www.gov.uk/government/collections/jobseekers-allowance-sanctions> accessed 28 October 2015; Office for National Statistics, 'Regional labour market, May 2015' (Newport: ONS, 2015) <http://www.ons.gov.uk/ons/rel/subnational-labour/regional-labour-market-statistics/may-2015/stbregional-labour-market-may-2015.html> accessed 28 October 2015; Minister for Social Development, AQW 46136/11-15, 2 June 2015; Minister for Social Development, AQW 46169/11-15, 9 June 2015

${ }^{131}$ See N Couling, 'Conditionality and sanctions: report to the Secretary of State' (London: DWP, 2013)

${ }^{132}$ The Northern Ireland labour market is consistently characterised by low employment rates, high levels of long term unemployment and a low jobs density indicator - see G Horgan, 'Child poverty in Northern Ireland: the limits of welfare-to-work policies' (2005) 39(1) Social Policy and Administration 49; S Donnelly (ed), Labour market bulletin 25 (Belfast: DEL, 2015)

${ }^{133}$ See L Harker, Delivering on child poverty: what would it take? (Cm 6951, London: DWP, 2006)
} 
This is the peer reviewed version of the following article:

M Simpson, 'Renegotiating social citizenship in the age of devolution' (2017) 44(4) Journal of Law and Society 646

It has been published in final form at

http://onlinelibrary.wiley.com.proxy1.athensams.net/doi/10.1111/iols.12061/full. This article may be used for non-commercial purposes in accordance with Wiley Terms and Conditions for Self-

Archiving.

easy case... the whole thing will be gamed and we will not get to the hard core of long term

unemployed who really need help" (civil servant). ${ }^{134}$

\section{WELFARE UNIONISM, NATIONALISM AND REGIONALISM: SITUATING RESPONSIBILITY FOR CITIZENS' ECONOMIC WELFARE}

If the nation state was once readily accepted as the "'natural' location for citizenship,"135 today "scales of social solidarity are shifting, no longer exclusively based on the nation-state." 136 The monolithic UK welfare state, if it ever truly existed, ${ }^{137}$ is being replaced by one in which "social citizenship rights are... expressed at different territorial scales."138 It is clear from interview data and political developments that elites in Northern Ireland and Scotland are uncomfortable with key aspects of recent UK government social security policy. In Scotland in particular, this discomfort appears to flow from a regional perspective on social citizenship that subtly, but genuinely, differs from that driving policy developments at Westminster. This Scottish vision is characterised by greater concern with poverty alleviation and a welfare-to-work model based on supporting, rather than coercing, claimants into employment. It is less clear that a Northern Irish ideology of social citizenship exists, but here, too, there are pragmatic concerns about the suitability of aspects of the UK approach and a view that cost-cutting and disciplinary measures have gone too far. However, dissatisfaction with how citizens' social rights are evolving under DWP's oversight is not necessarily a decisive argument for devolution of power to do things differently. Literature since 1998 suggests views on the appropriate locus of policy competence and the desirability of divergence are shaped as much by aspirations regarding the future of the political union. ${ }^{139}$

Marshall is typically depicted as a welfare unionist, associating social citizenship with the nation state and therefore situating responsibility for the definition and realisation of its attendant rights with the national government. ${ }^{140}$ From this perspective, only a national, relatively uniform welfare state can assure the social rights of citizenship to "all citizens equally." ${ }^{141}$ Certainly, Marshall's egalitarian dream of converting the social "skyscraper" into a "bungalow" ${ }^{142}$ would be more

\footnotetext{
${ }^{134}$ See J Rees, A Whitworth and E Carter, 'Support for all in the UK work programme? Differential payments, same old problem...' (WP115, Birmingham: Third Sector Research Centre, 2013)

${ }^{135}$ M Powell, 'The hidden history of social citizenship' (2002) 6(3) Citizenship Studies 229

${ }^{136} \mathrm{M}$ Keating, The government of Scotland: public policy making after devolution (Edinburgh: Edinburgh University Press, 2010) 42

${ }^{137}$ D Wincott, 'Social citizenship and social policy: Britain's welfare states' (2006) 36(1) Publius 169

${ }^{138} \mathrm{G}$ Lodge and A Trench, Devo more and welfare: devolving benefits and policy for a stronger union (London: IPPR, 2014) 10

${ }^{139}$ See G Lodge and A Trench, 'Devo more and welfare: devolving benefits and policy for a stronger union' (London: IPPR, 2014)

${ }^{140} \mathrm{G}$ Mooney and C Williams, "Forging new "ways of life"? Social policy and nation building in devolved Scotland and Wales' (2006) 26(3) Critical Social Policy 608; M Keating, 'Social citizenship, solidarity and welfare in regionalised and plurinational states' (2009) 13(5) Citizenship Studies 501

${ }^{141}$ I McLean, J Gallagher and G Lodge, Scotland's choices: the referendum and what happens afterwards (Edinburgh: Edinburgh University Press, 2013) 107

142 TH Marshall, 'Citizenship and social class' in TH Marshall and T Bottomore, Citizenship and Social Class (London: Pluto, 1992) 28
} 
This is the peer reviewed version of the following article:

M Simpson, 'Renegotiating social citizenship in the age of devolution' (2017) 44(4) Journal of Law and Society 646

It has been published in final form at

http://onlinelibrary.wiley.com.proxy1.athensams.net/doi/10.1111/iols.12061/full. This article may be used for non-commercial purposes in accordance with Wiley Terms and Conditions for SelfArchiving.

challenging in the context of significant regional differences in social entitlements or taxation. However, there is little evidence from Marshall's writing of preoccupation with the question of which tier of government should be responsible for the social rights of citizenship. Northern Ireland's devolved status goes unacknowledged in Citizenship and social class and Bottomore identifies failure to engage with the challenges posed to citizenship by separatist movements and strong sub-state identities as a key weakness of the Marshallian narrative. ${ }^{143}$

The logic of Marshall's teleology of citizenship, in which social citizenship flows from political citizenship, is that recent constitutional developments will undermine the primacy of the nation state in determining citizens' social rights. Social rights remained limited until extension of the franchise to poorer sections of the population, whose exposure to social risk was greater, facilitated articulation of demands for healthcare, education, housing and social protection, which political candidates could no longer ignore. ${ }^{144}$ Similarly, regionalisation of political citizenship via legislative devolution facilitates the expression through the ballot box of differing perspectives at sub-state level as to the form citizens' social rights should take. This in turn may lead to the emergence of distinctive regional welfare states to the extent that devolved competences permit - and social policy dominates the functions of the devolved institutions ${ }^{145}$ - or to demands for further devolution where the settlement cannot accommodate divergent ideologies of welfare or regional needs.

Social security was largely immune to divergence before 2012, due to lack of devolved competence (Scotland and Wales) and the parity convention (Northern Ireland). In 2009, following the Calman Commission's report, ${ }^{146}$ the UK government pronounced itself "deeply committed" to the maintenance of a single system. ${ }^{147}$ By 2012, under a new administration, it was breaking up national systems of discretionary welfare and council tax benefit in favour of local or regional replacements. ${ }^{148}$ In 2014, the leaders of the three main UK parties signed a 'vow' that further powers in fields including "welfare" would be devolved to Scotland if voters rejected independence ${ }^{149}$ and it should be no surprise if the renewed push for independence following the 2016 EU referendum is met with further social security devolution. ${ }^{150}$ Positions have also shifted in Scotland: the 1995 constitutional convention recommended that competence should be reserved in

\footnotetext{
${ }^{143}$ T Bottomore, 'Citizenship and social class, 40 years on' in TH Marshall and T Bottomore, Citizenship and social class (London: Pluto, 1992)

144 TH Marshall, 'Citizenship and social class' in TH Marshall and T Bottomore, Citizenship and Social Class (London: Pluto, 1992) 15, 32

145 D Birrell, The impact of devolution on social policy (Bristol: Policy Press, 2009)

${ }^{146}$ Commission on Scottish Devolution, Serving Scotland better: Scotland and the United Kingdom in the 21st century (Edinburgh: Commission on Scottish Devolution, 2009)

${ }^{147}$ Scotland Office, Scotland's future in the United Kingdom: building on ten years of Scottish devolution $(\mathrm{Cm}$ 7738, Edinburgh: Scotland Office, 2009) 4

${ }^{148}$ See Social Security Advisory Committee, 'Localisation and social security: a review' (OP14, London: SSAC, 2015) <https://www.gov.uk/government/publications/ssac-occasional-paper-14-localisation-and-socialsecurity>

${ }^{149}$ D Clegg, 'David Cameron, Ed Miliband and Nick Clegg sign joint historic promise which guarantees more devolved powers for Scotland and protection of NHS if we vote No' (Daily Record, 15 September 2014) <http://www.dailyrecord.co.uk/news/politics/david-cameron-ed-miliband-nick-4265992>

${ }^{150}$ M Simpson, 'Two (or three?) referenda and a general election: Brexit and devolved social security in Scotland' (Brexit, Regulation and Society, Manchester, June 2017)
} 
This is the peer reviewed version of the following article:

M Simpson, 'Renegotiating social citizenship in the age of devolution' (2017) 44(4) Journal of Law and Society 646

It has been published in final form at

http://onlinelibrary.wiley.com.proxy1.athensams.net/doi/10.1111/iols.12061/full. This article may be used for non-commercial purposes in accordance with Wiley Terms and Conditions for Self-

Archiving.

any devolution settlement. ${ }^{151}$ Fourteen years on this position had softened slightly, with Calman suggesting the UK government "explore" devolution of discretionary benefits. ${ }^{152}$ However, the Smith recommendation that housing benefit, welfare-to-work programmes and disability benefits should be devolved in full goes considerably further. ${ }^{153}$ Calman's proposal that the Scottish government gain little more than a right to lobby UK Ministers on the former two and the latter remain reserved was never likely to match the appetite for further devolution of an electorate that had already handed power to the secessionist Scottish National Party and 45 per cent of whom would vote for independence in 2014. Meanwhile, in Northern Ireland, although parity has not always been absolute, ${ }^{154} 2015$ saw the most dramatic rupture with the principle in 90 years, with a Bill modelled on the Welfare Reform Act 2012 failing to complete its progress through the Assembly. ${ }^{155}$ An equally dramatic reversal would follow, with Westminster temporarily handed competence to extend its reforms of 2012 and 2016. ${ }^{156}$ While the mitigations being introduced at regional level are largely minor and temporary, ${ }^{157}$ the shattering of the taboo that confined serious criticism of parity to back benchers is significant in itself, with Ministers and committee chairs openly voicing their concerns about coalition policy and disputing the region's scope for divergence. ${ }^{158}$

Rising demand for social security devolution following the electoral rise of the Scottish National Party and Sinn Féin from 2007 appears at first glance to fit the 'welfare nationalism' narrative of secessionist movements seeking to obtain a key trapping of nationhood for their regions. Interview data more closely resemble McEwen's reverse perspective, in which dissatisfaction with the UK's "retreat from the Keynesian welfare state" fuels nationalist sentiment, ${ }^{159}$ yet crucially the demand for greater autonomy was not limited to nationalist interviewees. Instead, welfare regionalism, a desire for a greater role for the region in determining the social rights of citizenship within the UK, emerges from political nationalists, (sometimes reluctantly) from unionists and very strongly from

${ }^{151} \mathrm{G}$ Leicester, Scotland's parliament: fundamentals for a new Scotland Act (London: UCL Constitution Unit, 1996); Scotland Act 1998 c46 sch 5 head F

${ }^{152}$ Commission on Scottish Devolution, Serving Scotland better: Scotland and the United Kingdom in the 21st century (Edinburgh: Commission on Scottish Devolution, 2009) 207

${ }^{153}$ Smith Commission, Report of the Smith Commission for further devolution of powers to the Scottish Parliament (Edinburgh: Smith Commission, 2014); see also Scotland Act 2016 c11 part 3

${ }^{154}$ Past points of divergence from Great Britain have included tighter residency criteria and reduced family allowance payments to larger families - see D Birrell and A Murie, 'Ideology, conflict and social policy' (1975) 4(3) J Soc Policy 243; T Fahey and E McLaughlin, 'Family and state' in AF Heath, R Breen and CT Whelan (eds), Ireland north and south: perspectives from social science (Proceedings of the British Academy'98, Oxford:

Oxford University Press, 1999) 128

155 Welfare Reform Bill (NIA Bill 13/11-15)

${ }^{156}$ Northern Ireland (Welfare Reform) Act 2015 c34; Welfare Reform (Northern Ireland) Order 2015 no 2006 (NI 1); Welfare Reform and Work (Northern Ireland) Order 2016 no 999 (NI 1)

${ }^{157}$ Welfare Reform Mitigations Working Group, Welfare Reform Mitigations Working Group Report (Belfast: OFMDFM, 2016)

${ }^{158}$ A Maskey, 'Sinn Féin calls for deferral of the Welfare Reform Bill' (Sinn Féin, 4 October 2012)

$<$ http://www.sinnfein.ie/contents/24642>; Letter from Mervyn Storey MLA to NI church leaders (20 October 2014) <http://www.irishchurches.org/blog/2014/10/welfare-reform-response-from-minister-mervyn-storey/> ${ }^{159} \mathrm{~N}$ McEwen, 'State welfare nationalism: the territorial impact of welfare state development in Scotland' (2002) 12(1) Regional and Federal Studies 66, 66 
This is the peer reviewed version of the following article:

M Simpson, 'Renegotiating social citizenship in the age of devolution' (2017) 44(4) Journal of Law and Society 646

It has been published in final form at

http://onlinelibrary.wiley.com.proxy1.athensams.net/doi/10.1111/iols.12061/full. This article may be used for non-commercial purposes in accordance with Wiley Terms and Conditions for Self-

Archiving.

Scottish civil servants; Northern Irish civil servants remain by far the strongest redoubt of welfare unionism. ${ }^{160}$

The connection between welfare regionalism and political reaction to the coalition's reforms means it is less clear that appetite for autonomy results from consideration of the best locus in principle of responsibility for income maintenance. This applies equally to the conversion of the Westminster elite to the devolutionist cause in 2014, which looks less the outcome of principled forward planning than a panicked response to a late poll suggesting Scotland might vote for independence. ${ }^{161}$

Subsequent negotiations on a new devolution settlement were similarly portrayed by interviewees as unconcerned with the most logical or effective division of powers, but fixated on point-scoring in favour of a unionist or nationalist perspective. The Smith Commission's deliberations were dismissed as "folk... putting stuff on the table and off the table in a pretty random and haphazard way" (politician), its report as a "cobbled together mixed bag" (politician), not "based on fundamental constitutional principles" (civil servant), but the outcome of "political negotiations" (civil servant) and "horse trading" (politician). Nationalist interviewees claimed unionists sought to preserve a centralised welfare state as "the glue that holds the UK together," regardless of Scotland's best interests. Unionists believed nationalists, having lost the referendum, sought to "push for everything up to and including independence" by maximising devolved competences, whether or not they had any firm idea how they might use these powers.

Northern Ireland had no comparable constitutional moment to the Scottish referendum and Smith Commission, but the significance of the near-tearing up of the 90-year-old parity convention should not be underestimated. The question of how to react to a 2012 Act heavily criticised by all major regional parties was complicated by the fact that, as civil servants observed, it was not one Stormont had previously been required to ask itself. Early, anti-devolution Unionist governments' "desire to treat [everybody] in the matter of legislation and benefit, precisely on the same level as similar people are treated in [Great Britain],"162 was subsidised by the UK government from $1926 .{ }^{163}$ The extent of this subvention remains the most significant obstacle to divergence; prior to 2012, even Ministers critical of Westminster policy treated preservation of the parity relationship and its financial transfers as the highest priority in social security. ${ }^{164}$ Consequently, civil servant interviewees were concerned that politicians were advocating divergence from Great Britain without due consideration of "the consequences of making those statements in terms of the budget position." Indeed, the last-ditch swerve back towards parity appears to be primarily due to the feared budgetary implications of persistence with the costlier pre-2012 system. ${ }^{165}$

\footnotetext{
${ }^{160}$ M Simpson, 'The social union after the coalition: devolution, divergence and convergence' (2017) 46(2) Journal of Social Policy 251

${ }^{161}$ W Dahlgreen, 'Yes campaign lead at 2 in Scottish referendum' (YouGov blog, 6 September 2014) <https://yougov.co.uk/news/2014/09/06/latest-scottish-referendum-poll-yes-lead/>

162 J Craig HC Deb 1 March 1929 vol 225 col 2361

163 Unemployment Insurance (Northern Ireland Agreement) Act 1926 c4

${ }^{164}$ A Attwood, NIA AQO 712/11

${ }^{165}$ See Northern Ireland Office, 'The Stormont House Agreement' (Belfast: NIO, 2014); Northern Ireland Office 'A fresh start: the Stormont agreement and implementation plan' (Belfast: NIO, 2015)
} 
This is the peer reviewed version of the following article:

M Simpson, 'Renegotiating social citizenship in the age of devolution' (2017) 44(4) Journal of Law and Society 646

It has been published in final form at

http://onlinelibrary.wiley.com.proxy1.athensams.net/doi/10.1111/iols.12061/full. This article may be used for non-commercial purposes in accordance with Wiley Terms and Conditions for SelfArchiving.

The key lesson from Northern Ireland's experience of social security devolution, then, is that devolved competences and dissatisfaction with the Westminster agenda do not necessarily result in legislative divergence. Responsibility for citizens' economic welfare appears to rest with the Assembly, but if the Assembly does nothing more than replicate Westminster legislation and the Executive receives money from the Treasury for its implementation, this may be an illusion. Scotland had already shown some appetite for divergence prior to 2016, using discretionary housing payments to compensate housing benefit claimants affected by the social sector size criteria and offering some increased generosity in the Scottish Welfare Fund compared to the discretionary social fund. Holyrood's new powers are more limited than Stormont's, but if greater political unity around a clearer ideology of social citizenship can override the inevitable budgetary challenges associated with steering a distinctive course, it may over time become possible to speak of a Scottish model of social security. When the limited mitigations and more critical attitude to parity in Northern Ireland are added to the mix, it is clear that small steps are being taken towards a situation where "welfare is no longer reserved or devolved, it's a shared set of responsibilities" (civil servant, Scotland). A challenge for actors at all tiers of government in the coming period may be to find a more constructive way of discharging that shared responsibility than the two years of "fighting" (politician, NI) reported to have occurred between Northern Irish and UK Ministers following the Welfare Reform Act 2012 and the mystifying refusal of the UK government to extend the remit of the Social Security Advisory Committee to include oversight of devolved functions in Scotland. ${ }^{166}$ Scottish policymakers face the additional question of how their vision of an enabling welfare-towork regime and a social security system based on dignity and respect can be realised when the minimum wage, rates of universal credit and conditionality regime remain reserved.

\section{CONCLUSION: SOCIAL CITIZENSHIP IN A CHANGING UK}

Social citizenship is in a state of flux both politically and theoretically. That the coalition government of 2010 to 2015 deliberately set about recasting social citizenship in the UK is not in doubt. Its impact on the welfare state was dramatic. In social security, fundamental to citizens' ability to enjoy a normal lifestyle, the coalition reshaped the minimum standard of living the state guarantees through an "unprecedented" reduction of the real value of benefits. ${ }^{167}$ It also intensified the obligations of jobseekers, increasing the price of non-compliance, and (furthering a New Labour agenda) moving increasing numbers of claimants into the activation pool, diminishing the role of illness and caregiving as alternative constructors of desert. In both cases the coalition agenda has been taken further by the current Conservative government - freed from the moderating influence the Liberal Democrats exercised in some areas ${ }^{168}$ - with further benefit cuts and expansion of the definition of a jobseeker. Reducing the living standards of the non-employed and low-paid is clearly in tension with Marshall's view that the social rights of citizenship are, at heart, aimed at ensuring

\footnotetext{
${ }^{166} \mathrm{G}$ McKeever, 'Legislative scrutiny, co-ordination and the Social Security Advisory Committee: from system coherence to Scottish devolution' (2016) 23(3) Journal of Social Security Law 126

${ }^{167}$ T Stephens, 'Income-replacement benefits, child benefit and inflation, 1992-2015' (London: Child Poverty Action Group, 2015)

${ }^{168} \mathrm{H}$ Bochel and M Powell (eds), The coalition and social policy: restructuring the welfare state (Bristol: Policy Press, 2016)
} 
This is the peer reviewed version of the following article:

M Simpson, 'Renegotiating social citizenship in the age of devolution' (2017) 44(4) Journal of Law and Society 646

It has been published in final form at

http://onlinelibrary.wiley.com.proxy1.athensams.net/doi/10.1111/iols.12061/full. This article may be used for non-commercial purposes in accordance with Wiley Terms and Conditions for Self-

Archiving.

each citizen can enjoy a "civilised" existence according to current standards. ${ }^{169}$. Reciprocity and a duty to work are not wholly alien to the Marshallian perspective, but an increasingly disciplinary social security system is at odds with some interpretations of Marshall as an advocate of relatively unconditional welfare rights. Perhaps, then, it is possible to argue that those parts of the welfare state in DWP's hands are waving a "long goodbye" to Marshall. ${ }^{170}$

On the other hand, in 2010 there was no evidence that the coalition desired far-reaching change to the tier of government responsible for citizens' economic welfare. Events in Scotland largely forced this upon Westminster, and perhaps fed into Northern Ireland's increased willingness to question the merits of parity. A common system may be justified as a necessary element of an equal citizenship or means of inter-territorial redistribution, but since 2012 devolved-level dissatisfaction with UK government policy has at times appeared to trump these considerations. Pressure for regionalisation does not emerge from consideration of the tier of government best placed to determine and guarantee the social rights of citizenship, but from the view that coalition policy was too miserly and/or punitive for regional circumstances or ideological preferences. Interview data and policy announcements suggest that Marshall's vision of a welfare state that underpins a civilised standard of living and takes a less disciplinary stance towards claimants remains alive and well among Scottish elites at least. Northern Irish interviewees, lacking ideological cohesion, tend to foreground more pragmatic grounds for divergence; although these have largely been overridden by budgetary concerns for now, findings point to a need for a new inquiry into the merits of parity that is not reactive to a specific piece of UK legislation.

Politically, this requires the UK government to decide whether it still aspires to relative uniformity of social protection and, if so, devise a more collegiate means of achieving this in cooperation with devolved administrations it can no longer dictate to. Theoretically, decentralised social security competences and regionalisation of the welfare state challenge mainstream interpretations of Marshall as a welfare unionist, but are shown here to be relatively compatible with his theory of citizenship. While tensions between decentralisation and hopes of an equal citizenship are acknowledged, progression from legislative devolution to divergence in social rights reinforces Marshall's account of social citizenship as emerging from the exercise of political rights. The fall-out from the Brexit vote confirms that neither the constitutional nor the social policy journey has reached the end of the road; Marshall's framework remains a useful basis for explaining the relationship between the two.

\section{Word count: 12,825}

\footnotetext{
169 TH Marshall, 'Citizenship and social class' in TH Marshall and T Bottomore, Citizenship and Social Class (London: Pluto, 1992) 8

${ }^{170}$ Recent reform of continental European welfare states has been characterised as a "long goodbye to Bismarck" - B Palier (ed), A long goodbye to Bismarck? The politics of welfare reform in continental Europe (Amsterdam: Amsterdam University Press, 2010)
} 